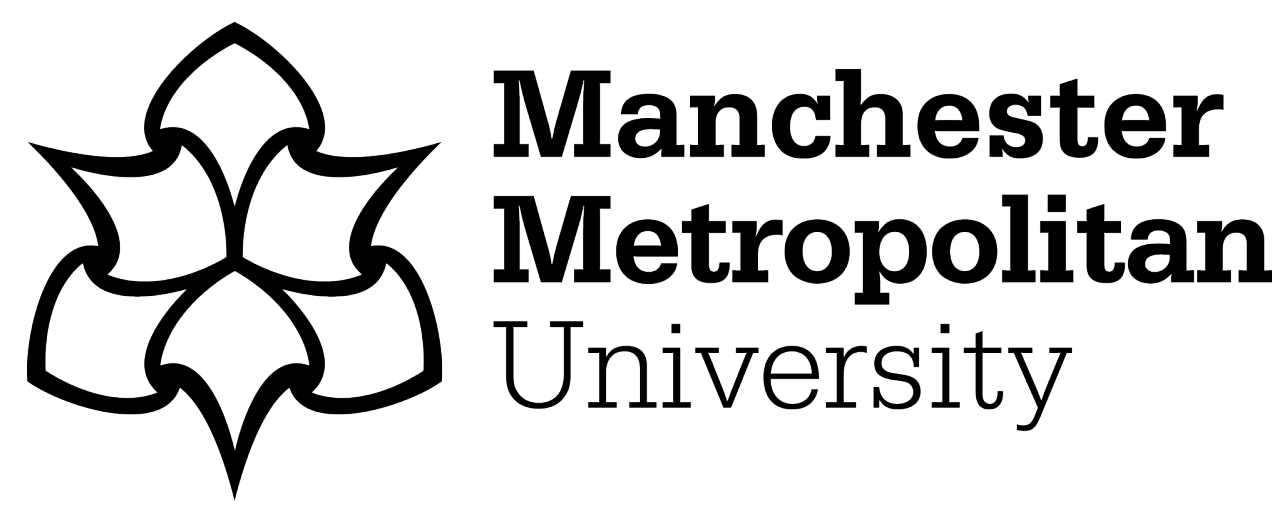

Salerno, JT and Dorobat, CE (2018) Currency depreciation and the monetary adjustment process: Reconsidering Lord King's contributions. Oxford Economic Papers, 70 (3). pp. 699-718. ISSN 0030-7653

Downloaded from: https://e-space.mmu.ac.uk/624735/

Version: Accepted Version

Publisher: Oxford Academic

DOI: https://doi.org/10.1093/oep/gpx044

Please cite the published version 


\title{
Currency depreciation and the monetary adjustment process: reconsidering Lord King's contributions
}

\author{
By Joseph T. Salerno ${ }^{a}$ and Carmen Elena Dorobat ${ }^{b}$
}

a Lubin School of Business, Pace University, One Pace Plaza, New York, NY 10038, USA; e-mail: jsalerno@pace.edu

b Leeds Trinity University, Brownberrie Lane, Horsforth, LS18 5HD, Leeds, UK; e-mail: c.dorobat@,leedstrinity.ac.uk

Abstract: This paper investigates Lord King's contributions in light of the renewed debate on international monetary policy coordination. We argue that King's work contains refined bullionist insights concerning currency depreciation, exchange rate determination, and balance of payments adjustment. We show how King's analysis of the monetary process under different currency regimes can help elucidate the effects of unconventional monetary policy on a global scale, concerning monetary spillovers, currency wars, business cycles, and the distribution of wealth.

JEL codes: B12; E41; E42; E52. 


\section{Introduction}

Economists in general—and monetary economists in particular- have gained tremendously in the past by revisiting the history of economic thought. This was certainly true in the immediate post-Bretton Woods era of the 1970s and early 1980s, for example, when the breakdown of prevailing approaches to the balance of payments and exchange rates gave rise to the modern monetary approach (Frenkel and Johnson, 1976). Explicitly built on insights pioneered by David Ricardo and the bullionists (Humphrey and Keleher, 1982), the modern monetary approach restored money to a prominent place in the long-run analysis of international monetary regimes.

We are now witnessing a similar paradigmatic upheaval in international monetary theory. An important case is the so-called 'taper tantrum' that roiled international markets during the summer of 2013 in the wake of Ben Bernanke's insinuation that the Fed would soon shift to a less accommodative monetary policy. These events have reinvigorated a debate on international coordination of monetary policy that began with the implementation of unconventional monetary policies in 2008 (Frieden and Broz, 2013; Feroli et al., 2014; Blanchard, 2016).

This paper reconsiders Lord King's contributions in light of these recent developments in international monetary economics. Modern commentary on the bullionist debate is uniform in its appraisal of Lord King's role in the controversy: generally recognizing King's popularity and influence, scholars characterize him as a master polemicist who merely expounded the monetary doctrines of more original and insightful thinkers, namely, Adam Smith, Boyd, Thornton, and Horner. ${ }^{1}$ However, we argue that King's original work propounded a 'complete' bullionist position, which revived the monetary process

\footnotetext{
${ }^{1}$ See Appendix for a detailed discussion of the historical context of Lord King's work, as well as of the influence that King's work had on his contemporaries and the significance attached to it by later classical and modern monetary theorists.
} 
analysis of Cantillon and Hume, and integrated insights from Boyd (1801) and Thornton ([1939] 1978). Thus, we aim to show that the more refined bullionist insights provided by Lord King's work can once more serve to elucidate some of the vexed questions at issue in the current debate over international monetary coordination.

These questions fall into two main categories: first, in the mainstream view, which developed during the Great Moderation, the gains from international monetary coordination are very small as long as national policymakers are pursuing 'good' policy-i.e. adherence to the Taylor principle - focused solely on domestic variables within the framework of floating exchange rates. This system results in the convergence to a unique and efficient global equilibrium. Second, the alternative view challenges the assumption that all countries follow good policy, especially when constrained by the zero lower bound. Its proponents argue that when some large countries, e.g., the U.S., deviate from good policy, the sizable effects on international variables induce other countries to deviate, resulting in multiple and excessively volatile global equilibria characterized by suboptimal capital and trade flows and exchangerate movements (Bullard and Singh, 2008; Taylor, 2013a; Bullard, 2014). It is now increasingly recognized that the current international monetary system facilitates and amplifies monetary spillovers, financial cycles and currency wars which impact domestic variables and policy choices (Frankel, 2015; Rey, 2015; Saccomanni, 2015), and that in this case the gains from international coordination may be very large.

However, what remains unclear is the character of these spillovers, the channels through which they arise, or whether they are harmful or beneficial (Eichengreen 2013). Other disputed issues concern the effectiveness of monetary policy, its long-run effects on output or the redistribution of wealth, as well as the credibility and direction of potential international coordination — such as monetary expansion or monetary discipline (Obstfeld and Rogoff, 2002; Frankel, 2016). These unanswered questions also underscore the difficulty in 
modelling the global effects of unconventional domestic policy ${ }^{2}$ (Taylor, 2013b; Claessens et al., 2015; Engel, 2015). According to Cœuré (2016), the precise role of wage and price rigidities, and temporal lags in monetary adjustment, or the relative relevance of demand shocks, supply shocks, or balance sheet effects are still debated. As a result, some scholars (Dreger and Wolters, 2014; Lim and Gan, 2015) have also begun investigating the theoretical foundations of these models, i.a. the demand for money in times of economic uncertainty, the drivers of currency depreciation and exchange rate adjustment, and the combination of real and monetary factors affecting current account imbalances. Yet, perhaps the most important development from our standpoint is that the concept of the 'International Monetary System,' which disappeared with the collapse of Bretton Woods, has returned to the literature (Borio, 2014; Taylor, 2016a, 2016b).

In this light, we believe that a fresh look at the underpinnings of international monetary theory, as well as at the classical monetary process analysis under different currency regimes, is both necessary and thought-provoking. This research avenue has been suggested by Leijonhufvud (1994), who argued for a 'backtracking' along the doctrinal tree to a distant decision node or a bifurcation where the development of a discipline followed one main branch instead of another through a sequence of decisions made by doctrinal followers. From this new vantage point, Leijonhufvud (1994, p.148) argues, 'some of the decisions made we may judge to have been wrong in hindsight', and we may gain some important perspective on the current state of the science by surveying the alternative branch. In what follows, we will endeavour to show why Lord King's neglected work is particularly relevant

\footnotetext{
${ }^{2}$ Romer (2016, p.6) argues that contemporary DSGE modelers rely on 'facts with unknown truth value' in calibrating the parameters of their models, and 'attribute fluctuations in aggregate variables to imaginary causal forces that are not influenced by the action that any person takes' (Romer, 2016, abstract). DeVroey (2016, p.380), also admits 'the rise of DSGE macroeconomics amounted to giving prominence to internal consistency over realism' but this development 'bears a heavy price, mainly that macroeconomists must refrain from claiming that the policy conclusions of their models have a direct policymaking bearing.' DeVroey (2016, p.388) adds, "whereas macroeconomics used to revolve around exchanges of ideas about reality, it was transformed by the [Lucasian] requirement to demonstrate propositions relating to a model economy.'
} 
today, as well as how his contributions can illuminate some of the abovementioned disagreements and inconsistencies in international monetary economics.

To this end, the paper is organized as follows: Section 2 examines Lord King's definition of the supply of money and his subjectivist approach to the demand for money, predicated on individual demand for cash balances. We also analyse King's discussion of the impact of real disturbances on the balance of payments and exchange rate. Section 3 details King's view of the monetary adjustment process and the temporal elements inherent in this process. In our discussion of King's work, we distinguish between three different monetary regimes, which we analyse in turn: a) a pure specie currency, b) a mixed system containing specie and convertible bank notes, and c) a system of inconvertible bank notes. We conclude by looking at potential ways of further incorporating Lord King's contributions in the ongoing debate over international monetary coordination.

\section{The demand for money and the exchange rate}

Lord Peter King (1776-1833), the seventh Baron of Ockham, Surrey was the descendent of a distinguished British family, a radical Whig, and a member of the House of Lords. His main work on the bullionist question was first published in 1803, but became greatly influential in the expanded and re-titled edition published the following year as 'Thoughts on the Effects of the Bank Restrictions' (King, 1804). King's contributions contain several important and original insights regarding the definition of money, the demand for money, and the determination of exchange rates. These remarks warrant special attention given the renewed scholarly interest in the theoretical foundations of international monetary policy discussions.

First, King employed a narrower concept of money that nominally endorsed the prevailing liquidity definition of money, but was substantially in accord with the medium-ofexchange approach. In the case of paper currency 'immediately convertible into specie at the 
option of the holder,' King (1804, p.5) contended 'the notes in circulation must be considered as equivalent to specie.' King's definition embraced 'all paper currency, whether payable at a future time or at the will of the holder; since both descriptions of notes may enter into receipts and payments and perform the office of money' $(1804$, p.2). Although King did not elaborate, 'paper currency payable at a future time' presumably referred to highly liquid financial assets such as bills of exchange, interest notes, or exchequer bills, which were widely utilized as media of payment in Great Britain during King's time.

The inclusion of these debt claims in the money supply represented only the briefest lip service to the liquidity approach. ${ }^{3}$ King $(1804$, p.2) qualified this statement explaining that his own work pertains 'principally to notes payable on demand.' He also expressly differentiated between 'currency,' comprising 'current coin or paper,' and the means by which 'all currency is economized,' such as bills of exchange, promissory notes, and 'the drafts of Bankers payable on demand' or demand deposits (King, 1804, p.18). Additionally, King (1804, p.6-7) describes exchequer bills and other interest-bearing government securities as 'very unfit media of exchange,' since they are exposed to fluctuations in value due to the fact that they 'lack power of immediate conversion into specie.' King also ignored Boyd's discussion of the nature of demand deposits and classified them with bills of exchange as near moneys by means of which the medium of exchange is economized.

The medium-of-exchange approach propounded by Smith, Boyd, and King quickly came to prevail over Thornton's liquidity approach. King's super-narrow monetary aggregate, excluding demand deposits, was also endorsed by Ricardo (1951, 4, p.58) and Mill (1965, p.536-7). In general, as O’Brien (1978, p.143) points out, 'deposits were excluded from the category 'money' by Classical writers', many of whom 'regard[ed] deposits as

\footnotetext{
${ }^{3}$ The proponents of the liquidity definition of money included Wheatley and Thornton, as well as prominent $18^{\text {th }}$-century monetary theorists including Hume (1970), Harris (1767), Vanderlint (1914), and Gervaise (1972).
} 
increasing velocity of circulation rather than as part of the money supply.' At present, demand deposits are included in all definitions and various metrics of the money supplyalbeit their importance as a guiding tool of monetary policy is often downplayed relative to other economic and financial data.

Second, King presented an analysis of the demand for money in terms of individuals' desires to retain a portion of their wealth in the form of currency. Fetter ([1965] 1978, p.38) characterized King's treatment as "modern in its suggestion of 'liquidity preference' and 'income velocity of circulation,' " but did not elaborate beyond this tantalizing hint. King's discussion is marked by the complete omission of the concept of the velocity of money, but this failure did not stem from ignorance given that King was intimately familiar with Thornton's extended discussion of the concept ([1939] 1978, p.96-102). ${ }^{4}$ King's rejection of velocity was logically entailed in his conviction that money is an integral element of the market economy and its exchange value is to be explained by the same economic laws as the market value of every other commodity. For King, 'the velocity of circulation is seen to be not an independent element affecting the value of money... the value of money is determined in just the same way as the value of other commodities' (Bowley, [1937] 1967, p.214-6).

King (1804, p.16) offers as the foil for his discussion the supposition that 'there is in all cases some given proportion between the wealth and industry of a society and the amount of its currency; and that this proportion is capable of being known and ascertained.' King's rejection of this supposition is not based on recognition of the potential variability of the objective factors that govern the velocity of money, but on the subjective and teleological element governing individuals' decisions to hold a stock of ready cash. For King (1804, p.17-

\footnotetext{
${ }^{4}$ Thornton ([1939] 1978) and Ricardo (1951) conceived of the demand for money as a given proportion of the aggregate amount of payments to be effected in the economy per period of time, depending upon the 'rapidity of circulation' of money. The 'rapidity' depends on institutional and cyclical factors: the availability of credit, the sophistication of banking techniques, and the state of confidence in financial markets.
} 
8), 'there is no rule or standard by which the due quantity of circulating medium in any country can be ascertained, except the actual demand of the public. The requisite proportion of currency, like that of every other article of use or consumption, regulates itself entirely by this demand; which differs materially in different countries and states of society, and even in the same country at different times.'

In this manner King lays the choice-theoretic foundations of the cash-balance approach. The emphasis on the primary role of subjective desires and anticipations of individual economic agents distinguishes King's Mengerian subjectivist cash-balance approach from the Hume-Mill-Fisher transactions approach as well as the Cambridge cashbalance approach — the two views on which modern treatment of the demand for money relies almost exclusively.

Accordingly, King construes the demand for money as a stock variable directly determined by the economizing decisions of market participants. These decisions are in turn influenced, but never determined, by a variety of objective factors, including levels of income and wealth, the availability and use of near moneys, the existence of banking institutions, and so on. Unlike proponents of the transactions approach, King does not distinguish between those factors that affect the velocity of money and those that operate directly upon the demand for money conceived of as a flow of commodities onto the market. All these factors affect the aggregate stock demand for money only through their influence on the cashbalance decisions of individual economic agents. Writes King (1804, p.18): 'Superior wealth and trade are causes which operate in themselves to increase the demand for currency; but they may be more than counterbalanced by other circumstances', such as various institutional developments by which 'currency is oeconomized.' These developments, however, may diminish the overall demand for money only to the extent that they induce economies in individual currency holdings. The establishment of banks, for instance, diminishes 'the 
quantity of current coin or paper, by rendering it unnecessary for individuals to retain large sums for their constant use' (King, 1804, p.18).

King is also cognizant of the impact of cyclical fluctuations upon the aggregate demand for money. Under given institutional arrangements, cyclical reversals of macroeconomic activity will modify individuals' expectations of future events and alter confidence in the financial markets, producing potentially large changes in desired levels of money balances. These concerns have recently been supported by research on the stability of money demand in times of economic uncertainty and financial insecurity (Dreger and Wolters, 2014; Lucas and Nicolini, 2015). As King (1804, p.19-20) expresses it: 'During a season of prosperity and confidence, the demand for currency... is much diminished by the facility of obtaining credit. The contrary effect takes place in time of alarm and insecurity, which produce unexpected calls for payment, and put all commercial persons under the necessity of increasing their stock of currency as a provision against contingencies.' King (1804, p.20) summarizes his discussion of the demand for money by reiterating the point that monetary demand is by nature a volatile and unpredictable variable, 'which depends in each case upon a great variety of circumstances, and which is diminished or increased by the greater or less degree of security, of enterprise, and of commercial improvement.'

Understanding the demand for money as demand to hold an asset leads King to a critique of the real-bills doctrine propounded by the antibullionist defenders of the Restriction. King (1804, p.20-3) lends elegance and clarity to Thornton's analysis ([1939] 1978, p.253-6) and takes it further by identifying the fundamental flaw in the real-bills doctrine as a confusion of the demand for credit with the demand for cash balances. To illustrate this confusion, King (1804, p.22) adduces 'a single practical instance of a great demand for discounts clearly unconnected with a general demand for currency.' Thus, during periods of economic stagnation and decline, the 'rate of mercantile interest' or the rate of 
return on business investment and the yield on government securities may exceed the maximum rate of interest on loans permissible under the usury laws. According to King (1804, p.22), 'under such circumstances, the merchants have a strong inducement to obtain money upon loans from the Bank [of England]; and the demand for discounts in consequence of this inducement may be carried to any assignable limit.' Conversely, reasons King (1804, p.22) during 'times of peace and prosperity,' when the rate of mercantile interest tends to be low, a diminution in the demand for discounts would occur. And, yet, it is precisely 'at these periods, in which commerce is most flourishing, the currency and circulation of the country would naturally be the greatest.' Thus, King underscores the point that variations in monetary demand bear no determinate relationship to variations in the demand for credit.

King also considered the exchange rate and the effects upon it of an excess supply of currency. This discussion is woven into his analysis of the process of currency depreciation as it runs its course under inconvertible paper currency—-described in more detail in section 3.3. At this point, however, it is worth highlighting the fact that King provided a statement of the purchasing-power-parity theorem. King's articulation of this doctrine warrants special attention, not only because of its conciseness and clarity, but because it has been completely ignored by doctrinal scholars - as credit for the theorem is usually assigned to Wheatley or Thornton (Wu, 1939, p.108; Angell, [1926] 1965, p.52; Humphrey and Keleher, 1982, p.287). In fact, both Wheatley's and Thornton's formulations of the theorem are imperfect when compared to King's. Moreover, King's discussion feeds into the now emerging consensus - rekindled over the last two decades by empirical studies (Taylor and Taylor, 2004) - that purchasing power parity theory is valid at least in the long run.

King (1804, p.31-2) writes:

The degraded currency of one country being balanced against the pure currency of another, an allowance is made for the degree of depreciation. 
An addition exactly equal to this amount is calculated upon all the debts of the former country; and the apparent increase of debts has a corresponding effect upon the rate of exchange, which is no longer a just criterion of the commercial transactions between the two countries. Though the imports and exports should be precisely balanced, though the debts and credits should be equal; yet, as the currencies differ in their intrinsic values, the exchange, though really at par, will appear to be unfavourable to that county where the currency is degraded.

King, in contrast to Wheatley, ${ }^{5}$ while upholding the view that the exchange rate is governed solely by monetary forces in the long run, allowed for the effect of real disturbances. According to King (1804, p.38-9), the 'natural effect of great and unusual remittances appears to have been aggravated by a depreciated currency. [...] the subsequent high price of bullion, as well as the unfavourable exchange, during the greater part of the year 1802 , is to be attributed solely to a depreciation of currency occasioned by the excessive issue of Bank paper.'

In devising an empirical test to determine whether a currency had been depreciated, King was again careful to allow for the effects of real factors, stating that 'as such causes of irregularity are occasional and temporary, it may be safely affirmed as a general rule that must ever remain true during the existence of the present commercial system of Great Britain [i.e. the restriction of specie payments] that an unfavourable exchange long continued is alone a decisive proof of a deranged and depreciated currency' (King, 1804, p.60).

His attention to short-run real phenomena also moved King to issue the caveat that the bullionist tests can only establish the existence, never the precise measure, of depreciation: 'nor will the most careful reference to the two tests of the price of bullion and the state of the exchanges enable us to ascertain in what precise degree a currency is depreciated; though the general fact of a depreciation may be proved beyond dispute' (King, 1804, p.40).

\footnotetext{
${ }^{5}$ Wheatley and Ricardo denied that nonmonetary factors could exercise any influence whatever on the exchange rate. Wheatley $(1819, \mathrm{p} .27-8)$ asserted that 'a foreign debt, from whatever cause it arises... has no tendency to draw money out of the country, unless our currency is relatively too great.'
} 
Further evidence that King was alert to the influence of real factors on the exchange rate is provided by his formulation of the distinction between the nominal and real exchange rates. Credit for this analytical innovation has been attributed by O'Brien (1978) and Humphrey and Keleher (1982) to the moderate bullionist, William Blake, whose tract was published seven years after King's. While Blake (1966) elaborated the distinction at greater length and used the terms somewhat differently, King (1804, p.37-45) also expounded the distinction and employed it in his analysis.

For King, the 'par' rate of exchange $(\mathrm{P})$ referred to the exchange rate stated in terms of the pound price of a unit of foreign currency, as it stood when the price of bullion equalled its mint par prior to the onset of the Bank Restriction; the 'nominal' rate $(\mathrm{N})$ designated the exchange rate actually observed at any point in time and determined by momentary supplyand-demand conditions on the foreign exchange market. Although King did not give it an explicit designation, the long-run equilibrium rate of exchange (E) corresponded to the purchasing-power-parity rate. Because the equilibrium rate is not directly observable, King employed the percent deviation of the current price of silver from its mint price to estimate it. The real rate $(\mathrm{R})$ King computed by multiplying the nominal rate by the ratio of the par to the equilibrium rate, i.e., $\mathrm{R}=\mathrm{P} / \mathrm{E} \times \mathrm{N}$. Variations of the real rate therefore reflect only the transient influences on the exchange rate of the real changes continually occurring in commodity and capital markets. Thus when the real rate exceeds the par rate King spoke of the 'real exchange' or 'real balance' as being 'unfavourable' and when the real rate stands below the par rate he referred to it as 'favourable' (King, 1804, p.37-45).

An example of King's use of this analysis is his explanation of the British exchangerate experience between 1802 and 1804. According to King (1804, p.41-2), 'During the year 1802 the nominal balance was 5 per cent in favour of Hamburgh: but it is probable that the real exchange was in favour of England; there being reason to believe, from the high price of 
silver [as a proxy for the purchasing-power-parity rate] that the favourable balance of trade was counteracted by a depreciation of Bank notes to the amount at least 5 per cent.' By early 1804, the nominal exchange rate had appreciated back to equality with the par rate, while the equilibrium rate as measured by the premium on silver bullion now stood depreciated by nine to ten percent, prompting King (1804, p.41) to argue that 'This extraordinary difference is rendered intelligible by supposing Bank notes to be depreciated, and the real balance of trade very different from the nominal, but by no other hypothesis.'

\section{The monetary adjustment process}

One of King's most important contributions was his revival of monetary process analysis (Sekine, 1973; Salerno, 1980), elements of which had been expounded by a long line of British writers (Harris, 1767; Vanderlint, 1914; Cantillon, 1964; Hume, 1970; Gervaise, 1972). With varying degrees of insight and elegance, they contributed to the elaboration of a sophisticated approach to analysing domestic and international adjustments occurring in response to variations in the supply of and demand for a pure commodity money. However, this approach was cast into a deep shadow by the comparative-static analysis of monetary phenomena developed by Smith $(1965)^{6}$. Variants of this latter approach are still in use in current monetary analyses, which trace international monetary adjustment following a periodby-period nominal price setting, or by allowing for nominal rigidities and imperfect competition, i.e. staggered price setting (Clarida et al., 2002).

\subsection{Adjustment under pure specie money}

\footnotetext{
${ }^{6}$ While Boyd's and Thornton's earlier publications successfully challenged some aspects of Smith's approach, King renewed and refined the process analysis of pure commodity money, and adapted it to the circumstances of convertible and inconvertible paper currencies.
} 
To explain the determination of the value of a pure commodity money within the framework of the 'closed' world economy, King adheres to the doctrine propounded by Hume, Harris, and Smith (Humphrey and Keleher 1982, p.42-63). ${ }^{7}$ According to this doctrine, the purchasing power of money or, inversely, the general level of prices is established by the interaction of the existing total stock of the money commodity and the demand for it in both monetary and nonmonetary uses. King (1804, p.2-3) writes: 'The metals... are employed either in manufactures, or as current coin, or in the form of bullion for effecting the exchange between nations; and their value will consequently depend upon the degree in which the supply for these different purposes is proportioned to the demand. It must rise or fall as the demand in each particular instance is increased or decreased.' On the other hand, King (1804, p.116-7) argues, 'a general increase of prices and diminution in the value of money' result from 'an actual addition to the precious metals from the American mines.'

King does not refer to the cost of producing precious metals as a determinant of the value of money, because King appears to have rejected the Smith-Ricardo view that cost-ofproduction operates as the long-run determinant of the exchange value or price of reproducible goods. Thus, King (1846, p.235) declares, without qualification, 'in all cases the price of every thing whatever is regulated by the supply and demand.' Further evidence of King's view, as well as of his influence, is found in a letter by Ricardo to Malthus, wherein its author expresses 'astonishment' that Lord King, Wishaw, and Malthus 'agree... that the measure of value is not what I have represented it to be; that the natural price, as well as market price, is determined by the demand and supply, - the only difference being that the

\footnotetext{
${ }^{7}$ The 'closed' economy is a model that permits us to abstract from the effects on exchange rates and the balance of payments when analysing monetary and fiscal policies or cyclical shocks. The closed economy may be imagined either as the entire world economy or as an autarkic national economy with no trade or financial relations with the rest of the world.
} 
former is governed by the average of permanent demand and supply, the latter by the accidental and temporary' (Ricardo 1951, 7, p.250).

Regarding the international distribution of money, King accepts without reservation the principles of eighteenth-century monetary process analysis, according to which an equilibrium global distribution of the money commodity exists when its value or purchasing power in terms of the complete array of nonmonetary commodities-abstracting from transportation costs - is internationally equalized. This analysis implies that long-run flows of money through a nation's balance-of-payments are part and parcel of the process by which disequilibrium in its domestic money market is adjusted. King, however, does not rest content with conducting 'comparative static experiments' (Girton and Roper 1978, p.612); he is concerned to elucidate the adjustment process by which a new monetary equilibrium emerges from a disturbance of the previous equilibrium.

King's analysis begins with his insight that people are not indifferent to the stock of money they hold and always seek to economize on their holdings. The reason is that 'every superfluous quantity in the hands of individuals is attended with a positive loss to the holder. There is therefore a constant effort on the part of each individual to reduce the quantity as much as possible' (King, 1804, p.104). For King, then, the key element in his account of the monetary adjustment process is the real balance effect, defined by Patinkin $(1965$, p.598) as 'that crucial intermediate stage where the monetary increase makes individuals feel their cash balances are larger than needed so that they can expand their purchases accordingly.'

According to King (1804, p.105), in the case of a nation whose currency consists purely of specie or of a mixture of specie and convertible paper, its nominal money stock is rendered completely endogenous by the fact that 'the same inducement to diminish the quantity and prevent the excess of currency must operate in all given cases, and whether the medium of exchange consists of coin or paper.' In either case, individual currency holders 
will react to monetary disequilibrium in a manner which will prompt an international process of adjustment. According to King (1804, p.104-6):

Where the currency of a country consists entirely of the precious metals... if the quantity of specie is improperly increased, whether by Government or from other causes, it will immediately be reduced within its due limits by the care and attention of individuals, which will always prevent any permanent excess of the circulating medium. ...In a mixed circulation of coin and notes there can be no permanent superfluity of the latter, because they would in that case be exchanged for gold.

The efforts by individuals to draw down their excess cash balances will have an impact on the national balance of payments via both Humean relative price effects and direct expenditure effects. It is the latter that have received almost exclusive emphasis in the modern monetary approach with its real-balance orientation.

King also alludes to international money-commodity flows that occur without the intermediation of relative price changes. The transfer of rent payments from Irish tenants to landlords residing in England 'is much assisted by the fact itself which creates the demand for the remittances. [It] has the necessary effect of diminishing Irish imports, because expenditure of revenue is transferred to another country; and it also increases the export of the product which is no longer consumed at home' (King 1804, p.86). This disturbance of balance-of-payments equilibrium has a real source rather than monetary source. King's analysis shows, however, that he conceives shifts in the demand curve as an integral part of the adjustment process. In fact, it contains 'the first delineation of a demand-shift transfer of unilateral payments in which the effect of the transfer of purchasing power is explained as a reduction in the consumption of exportables in the paying country, freeing additional commodities for export, rather than merely implied' (Mason, 1953, p.132).

At the same time, King does not ignore or downplay the role of Humean relative-price effects in the international adjustment mechanism. He envisages monetary disequilibrium as 
initially a local phenomenon, whose full eradication is never instantaneous but involves a time-consuming process featuring a sequential adjustment of commodity prices. According to King (1804, p.48-9), 'every increase of an unlimited [i.e. inconvertible] paper currency beyond that quantity which would naturally circulate must have the same effect as an increase of gold and silver; and occasion a corresponding advance of prices. But the effect is not produced immediately upon the issuing of notes; and some time must elapse before the new currency can circulate through the community and affect the prices of all commodities.'

Therefore, international divergences in the purchasing power of money invariably emerge as an immediate response to a domestic monetary disequilibrium and call forth equilibrating flows of money and commodities through the balance of payments. Moreover, the continual and unpredictable maladjustments between local stocks of and demands for money and the consequent interlocal discrepancies in money's purchasing power constitute the reason for the extension of the division of labour and specialization to 'the bullion trade': the trade of bullion is no longer carried on by the general merchant who deals in ordinary commodities, but the bullion merchant whose peculiar business it is to adapt the supply of the precious metals to the demand, bring them from those places where they are cheap to others where they are dear, and thus to reduce the value of gold and silver in all countries as nearly as possible to one level (King, 1804, p.156).

King's clear recognition of the time element in market adjustment processes, which restrains him from embracing the notion of instantaneous arbitrage of the value of money, also leads him to entertain the possibility that real forces can have an impact on the balance of payments in the short run - as we also observed above in our discussion of the exchange rate.

According to King, nonmonetary or real disturbances of a nation's balance-ofpayments equilibrium may result from such events as poor domestic harvests, subsidies to foreign allies, or capital flight and, independently of any change in the monetary fundamentals, cause an outflow of specie that temporarily reduces the domestic money stock 
below its long-run equilibrium level. As an example, King (1804, p.83-4) argues that a nation possessing no mines 'does not export any part of its gold or silver except upon some sudden and unforeseen emergency not connected with the ordinary course of commerce... [when] the price rises beyond its natural level, and forces out a part of the specie and of that average quantity of the precious metals which is required for commerce and manufactures.' However, despite this admission, King consistently holds that the balance of payments and the exchange rate are fundamentally monetary phenomena which cannot be analytically isolated from the overall monetary adjustment process.

\subsection{Adjustment under a mixed system of specie and convertible bank notes} At the close of the eighteenth century, the prevailing approach to banking and convertible paper currency entailed "a crude form of the "Banking Principle"” (Horsefield, 1953, p.1). According to this principle, as long as bank notes are issued only in the discount of 'real bills of exchange' and are immediately convertible into specie upon demand, the quantity and, hence, the value of money in the nation of issue would not be affected, even in the short run. King, however, deserves recognition for integrating the contributions of the eighteenthcentury monetary theorists with the diffuse insights and criticisms contributed by Boyd and Thornton to provide a complete and coherent account of the monetary adjustment process under a convertible paper currency.

In his analysis, King distinguishes between an 'open' domestic economy and the 'closed' world economy. While recognizing the endogeneity of the domestic money stock in an open economy, King avers the applicability of supply-and-demand theory in explicating the effects of a single nation's issuance of specie-convertible bank notes on the global value of specie money. 
King (1804, p.2) takes as the point of departure for his analysis Smith's conclusion that 'as each portion of paper displaces an equal quantity of coin, the value of the precious metals is not affected by this change of currency.' In his estimation, this 'is not however a correct representation of facts,' because King refuses to adopt Smith's assumption of the individual nation as a price-taker on world markets. ${ }^{8}$ He argues that 'the substitution of paper for specie... so far as it displaces the coin which would otherwise be employed... diminishes the demand for those metals for the purpose of coinage, and has precisely the same effect in reducing their general value as an actual increase of quantity to the same amount' (King, 1804, p.3). Moreover, King emphasizes that, because gold and silver serve as international media of exchange, the fall in their respective purchasing powers is not confined to the nation issuing bank notes, but ultimately is transmitted throughout the world economy. The result is that 'the actual reduction in the value of gold and silver, which is produced by the paper circulation of any particular country, is in proportion of the amount of such circulation to the whole quantity of the precious metal applicable to the purposes of coinage and commerce throughout the world' (King, 1804, p.3-4).

King is however prepared to accept Smith's conclusion regarding the practically negligible effect on the international value of specie that results from a single nation's emission of paper currency in the form of bank notes unbacked by specie reserves (i.e. fiduciary media). For King (1804, p.4), Smith's observation is 'true for all practical purposes,' because 'the extension of paper credit, which takes place in common times and

\footnotetext{
${ }^{8}$ As Eagly (1970, p.65) notes: 'The world demand for specie thus appears to an individual nation as infinitely elastic with respect to its price in terms of commodities.' A similar statement appears in Eagly (1974, p.77). Bloomfield (1975, p.485) describes Smith's view that 'any excess supply of money will be drained abroad in the form of specie as individuals adjust to their excess holding of cash balances by increasing their foreign expenditures,' i.e., without the intervention of relative price effects, as anticipating 'however crudely, the modern 'monetary approach' to balance of payments theory and adjustment.' Petrella $(1968$, p.372) refers to Smith's 'automatic-export-of-surplus-metals principle.' Humphrey and Kelleher (1982, p.137-38) emphasize, 'Smith clearly viewed money as a dependent variable and, as such, indicated that it would be automatically supplied to the small open economy. ...[M] oney was viewed as fully endogenous or passive.' Arnon (2010, p.48) also characterizes Smith's view of a nation's quantity of money as 'demand-determined' with 'the endogenous money supply follow[ing] the dictates of the balance of payments, price levels and so forth.'
} 
under ordinary circumstances, can only produce a very gradual depreciation, which being shared by the world at large, is not felt as an inconvenience by any particular country.' And, indeed, 'experience seems to shew that no considerable depreciation is ever produced in this manner.'

King's analysis of the long-run effects of the issuance of convertible paper currency does not represent so much a breaking of new ground as it does a return to the theoretical approach of British monetary theorists before Smith, whose theorizing on banks was conditioned by the undesired practical consequences of John Law's doctrines - to which Smith was more favourable (Salerno, 1980, p.212-3). Their approach to fractional-reserve banking and bank notes turned on the insight that creation of fiduciary media in an open economy, no less than an addition to the stock of precious metals, generates an excess supply of money, which initially inflates domestic prices and incomes and is eventually cleared by the efflux of specie through the balance of payments - as a consequence of direct-expenditure or relative-price effects, or both. King's critique of Smith completes this analysis by demonstrating that the bank-created excess supply of money is finally and fully equilibrated in the closed world economy by a global decline in the purchasing power of specie money. Nevertheless, as mentioned above, King concedes that this decline is likely to be imperceptible when the emission of fiduciary media is undertaken by the banking system of a single nation-— thus echoing the mainstream view which uses a similar argument to support the view that in this case, gains from international monetary coordination are insignificant.

King (1804, p.105) thus affirms that monetary disequilibria are adjusted in the same manner, whether the domestic money stock is composed purely of specie or contains elements of convertible paper currency: 'the same inducement to diminish the quantity and prevent the excess of currency must operate in all given cases, and whether the medium of exchange consists of coin or paper.' In either case the real balance effect will operate to 
induce currency holders to undertake those actions which promote the emergence of a new equilibrium in the domestic money market.

However, King does not ignore the details of the time-path connecting successive monetary equilibria, and contributes what was lacking in Smith, Boyd and Thornton-and by extension, in current models of the global monetary equilibrium-, namely 'a full account of the mechanism whereby economic agents are actually induced to send gold abroad by the introduction of paper money' (Laidler, 1981, p.191). In fact, King's microeconomic description of the series of adjustments undertaken by economic agents in response to the disturbances of their individual cash balance equilibria resulting from the emission of bank notes is embedded in a complete theory of the competitive supply of currency, elaborated in his chapter 'On Country Banks' (King, 1804, p.87-111).

King explicitly argued that the process that serves to clear an excess supply of money in a nation endowed with a pure specie money functions in the same manner to adjust a localized monetary disequilibrium created by the emission of convertible bank notes. According to King (1804, p.105): 'The notes of the private banks... are regulated by the same principles [as specie]. So far as they are necessary for effecting the payments and circulating the wealth of the district, they merely supply the place of the specie which would otherwise be employed, and cannot therefore affect the general value of money. If they exceed the quantity which is requisite for these purposes, the excess will be returned upon the Bank, to be exchanged for the currency in which they are payable.'

While King heavily emphasized the direct expenditure effect in the process of interlocal clearing of excess supplies of money, he did not neglect the equilibrating function of interspatial divergences in the purchasing power of money. For instance, in addressing the case of an excess issue and depreciation of bank of England notes, King (1804, p.109) wrote 'if there was not a corresponding excess of country bank notes, the relative proportion of 
prices would be altered between London and those parts of the country where the currency was carried on in some more valuable medium, and exchange would take place between London and the several districts of the provincial banks in favour of the latter and against the metropolis." 9

\subsection{Adjustment under inconvertible paper currency}

King's emphasis on the real balance effect and on the time-related distinction between transition effects and permanent effects was most evident in his description of the course of monetary depreciation under a regime of inconvertible paper currency.

According to King $(1804$, p.6), 'if the currency should exceed that quantity which the effective demand of the public requires,' there results a process of 'depreciation.' This process is precipitated by the actions of those who first come into possession of the newlycreated currency, and it involves a step-by-step increase in the array of individual commodity prices as the excess balances are spent and re-spent throughout the entire economy, a process which continues until the purchasing power of money is finally reduced to its new equilibrium level.

King (1804, p.50) acknowledged Hume (1970) as a forerunner in this type of monetary process analysis. However, unlike Hume, whose analysis had proceeded on the

\footnotetext{
${ }^{9}$ King's also recognized the role of competition in the currency supply process, which explains his approach to banking policy, and was to characterize all the later bullionist writings with the notable exception of Wheatley's. This position was best exemplified in a warning that King (1804, p.110-1) issued at the conclusion of his chapter on country banks:

[T]o suppress the circulation of [country banks'] notes, or to restrict them in any manner tending to give an exclusive privilege to the bank of England, would be as unjust and impolitic as to grant a monopoly of any other branch of skill and industry to any private merchant or company. When we consider the nature of the banking system, of all branches of trade the most complex and delicate, and deriving its very essence and existence from the confidence of the Public, it will appear that there is no subject upon which legislative interference would be more improper or pernicious.
} 
basis of an assumption of unemployed labour ${ }^{10}$, King did not identify the increase of aggregate output as a significant effect of the lagged and uneven adjustment of commodity prices to a disturbance of monetary equilibrium. Rather, he used the earlier process analysis of Cantillon in deducing that the inevitable time-lapse between cause and effect in monetary adjustment processes generally produces a redistribution of income and wealth in society. King (1804, p.48-9) explained:

It is this interval between the creation of new paper and the rise of prices which may be a source of advantage to the persons who obtain loans from the Bank. The merchant, to whom the notes are immediately issued, employs them in the purchase of goods at the prices which they then bear, or is enabled by the payment of a former debt to obtain credit for them at those prices. But by the very effect of these notes when they are afterwards circulated, the price of goods is enhanced; and the merchant has the advantage of trade. If he is an exporting merchant, he will receive, besides the usual profit, the amount of the depreciation which will have taken place in the currency between the time of purchasing the goods and the arrival of the remittance in return.

King's analysis led him to identify the primary beneficiaries of the Restriction as the stockholders of the Banks of England and Ireland and the merchants who discount with these institutions. Alluding to the seignorage derived from the unrestricted creation of convertible Bank of Ireland notes, King (1804, p.64) likened their resulting depreciation 'to an income tax which is levied not for the benefit of Government, but the proprietors of Irish Bank stock.' Elsewhere, King (1804, p.69) noted the bonuses and dividends paid by the Banks of England and Ireland to their shareholders since the inception of the Restriction, and

\footnotetext{
${ }^{10}$ Over the years several doctrinal scholars have recognized that the starting point of Hume's analysis was implicitly a state of less than full employment. These include: Monroe ([1923] 1965, p.166-67); Vickers ([1959] 1968, p.227-28); and Rotwein ([1955] 1970, p.lxiv-lxv). Rotwein points out the inconsistency between Hume's assumption of initial unemployment and his conclusion that the quantity effect of the influx of new money is completely reversed at the end of the adjustment process. More recently Arnon (2010, p.16, 24) has argued that, in a few places, Hume's analysis of the neutrality of money 'was modified to include some short term nonneutralities.' Paganelli (2006), however, maintains that Hume consistently adhered to 'pre-modern theories of money' tracing back to Aristotle in which the quantity of money was an endogenous outcome of trade and industry, which were in turn activated and increased by expanding wants and a growing aggregate demand for goods.
} 
concluded that it is not mere coincidence that the main supporters of the Restriction included those who borrowed from the Banks. Stated King (1804, p.50-1):

The merchants of London and Dublin are probably little acquainted with the writings of [Hume], and have never perhaps very accurately traced the steps of the preceding argument. But their experience has undoubtedly led them to the same conclusions; and there can be no doubt that since the period of the Restriction discounts have been obtained from the Bank by commercial men with less difficulty, and that these accommodations together with the profits derived from hence have given their minds a strong bias in favour of the measure.

Although pushing beyond Hume to the rediscovery of Cantillon's insight relating the distribution effects of monetary inflation to the short-run non-neutrality of money, King did not attain here Cantillon's further insight that money is non-neutral even in the long run-i.e. that the monetary adjustment process can never finally yield a price level that varies equiproportionally with the money stock (Cantillon, 1964). Similar views on monetary nonneutrality—closer to the sense in which Cantillon and King envisaged it—have been reintroduced in current research. They underscore the idea that unconventional monetary policies — leading to monetary spillovers, crises, and currency wars — have irreversible effects on domestic variables such as the structure of output, relative prices, and the distribution of wealth (Cheng and Angus, 2012; Hoffmann and Schnabl, 2016).

For example, King (1804, p.31-2) argued that inconvertible paper currency 'if multiplied beyond the demand, must be depreciated in the degree of its excess. In the course of commercial dealings this increase of quantity is soon discovered; and prices are increased in proportion.' Later, however, King (1846, p.278-79) reversed himself on the subject, arguing that a permanent redistribution of wealth and corresponding reorientation of the economy's production structure had indeed resulted from monetary inflation: 'through the means of the increase of the quantity of the currency, a rise of prices, had changed the distribution of wealth, and the employment of capital. By putting an end to the restriction, an 
alteration in the employment of capital, and the distribution of wealth, must be produced in an opposite direction to that which the depreciation of the currency had produced.'

Here also King (1846, p.279) recognized the phenomenon of 'forced saving,' the increase in capital investment which results when real income is transferred from labourers to entrepreneurs during the process of monetary depreciation. This type of analysis has now been relegated to the history of economic thought, but as Ahiakpor $(2009$, p.144) argues, 'before... Keynes's economics took hold in modern macro-economics, employing the forcedsaving mechanism was a commonplace.' While King's discussion of forced saving was preceded in time by those of Thornton and Malthus (Hayek, [1932] 1969), King advanced further than both and suggested a relationship between forced saving and 'the system of overtrading,' that is, the boom-bust cycle.

In discussing the merits of this classical doctrine, and its role in business cycle theory, Ahiakpor $(2009$, p.145) argues that 'one really does not need the equipment of modern mathematical economics to explain the short-run non-neutrality of money on output and employment from the phenomenon of lagging factor prices behind changes in the price level... All one needs is a lack of full anticipation of changes in the quantity of money and the price level, which is entailed in the classical explanation.' Although the meaning of the term 'forced savings', in relation to the increase in investment and the evolution of consumption during economic booms and busts is still disputed (Ahiakpor, 2008; Garrison, 2008; Salerno, 2012), this nevertheless shows the ongoing usefulness of classical doctrines for modern macroeconomics.

In King's view, furthermore, it was not only increases in the supply of currency unmatched by increases in its demand which cause depreciation; he also identified expectations as a cause of fluctuations in the purchasing power of money. King's prescience in this regard is worth highlighting, as it was only in the 1970s when the role of expectations 
was fully acknowledged by contemporary monetary research. Even so, scholars still encounter difficulties in modelling the impact of expectations on the exchange rate and the international monetary equilibrium (Broz and Frieden, 2001, p.322-23), particularly if their framework includes various aspects of money non-neutrality (Moreira et al., 2016).

King (1804, p.5-6) argued that once its link with gold has been severed, a currency no longer has a 'determinate value' and, therefore, 'is in danger of being depreciated from two different causes; viz. by want of confidence on the part of the public, and an undue increase of the quantity of notes.' Recognizing that a fundamental change in the monetary regime will radically alter expectations, King contended that even if those charged with regulating the supply of an inconvertible currency 'should confine their issues within the most just and reasonable limits; yet if their credit or solvency is doubted, it is impossible that their notes can circulate at the full nominal value' (1804, p.5-6). Furthermore, King maintained, 'similar depreciation must take place' as a result of an increase of the quantity of currency in excess of its demand and despite the public's 'most implicit confidence' in the issuer. Alluding to historical instances of the issue of indefinitely inconvertible currencies in Europe and the American colonies, King concludes that 'in every known instance such notes have uniformly been depreciated; probably by the joint operation of both the causes' (1804, p.5-6).

It is true that in this discussion King did not explicitly establish the intermediate links between loss of credibility in the monetary authority and a fall in the demand for money, and between the latter and the depreciation of the monetary unit. Nonetheless, his cognizance of these may reasonably be inferred from his conception of monetary demand as a demand to hold cash balances in conjunction with his position, noted above, that the value of any good, including money, is determined solely by the forces of supply and demand. 


\section{Conclusion}

The virtue of Lord King's analysis is that it integrates into a unitary adjustment process the short-run and long-run effects on domestic and international variables of monetary shocks. Although focusing primarily on the analysis of monetary shocks, King, unlike Ricardo, does not ignore real shocks. Furthermore, although King is intent on tracing out how domestic and international monetary equilibrium is re-established after a given shock, his analysis is implicitly dynamic in the sense that it takes into account the sequence and timing of the endogenous changes (e.g., in the demand for money) that intervene between the initial and final equilibria.

In our contemporary world of tightly integrated and globalized markets for goods and assets, King's approach to the monetary adjustment process is highly instructive. For King and other bullionist writers did not distinguish between open and closed national economies. The only closed economy was the world economy, and all variations in money caused changes that precipitated interspatial adjustment processes that operated with indifference to political boundaries. This is in sharp contrast to contemporary macroeconomic research, which—even after the global financial crisis—continues to devote the lion's share of its analysis to closed-economy models while 'opening up' the macroeconomy as an afterthought (Abel et al., 2011; Hubbard et al., 2012; Froyen, 2013).

A broader point to be made, however, is that contemporary macroeconomics, and international monetary economics in particular, has become subject to deep dissatisfaction among some of its most noted practitioners - and not merely because of the failure of its models to forecast the financial crisis and the Great Recession. In the present paper we have endeavoured to provide just one example of the application of the technique of doctrinal 'backtracking' that can propel monetary macroeconomics forward. We believe this highlights the importance of drawing attention to the neglected contributions of a writer like Lord King, 
and provides an alternative approach that may enrich the current discussion concerning the effects of international policy coordination.

\section{Supplementary material}

Supplementary material — the Appendix and the Data files — are available online at the OUP website.

\section{Acknowledgments}

The authors would like to thank two anonymous referees for their helpful comments and suggestions on an earlier draft of this paper.

\section{References}

Abel, A.B., Bernanke, B.S. and Croushore, D. (2011) Macroeconomics, $7^{\text {th }}$ ed., AddisonWesley, New York, NY.

Ahiakpor, J.C.W. (2008) Garrison on Mises and Forced Saving: Arguing the Implausible?, History of Political Economy, 40, 383-95.

Ahiakpor, J.C.W. (2009) The Phillips Curve Analysis: An Illustration of the Classical Forced-Saving Doctrine, Journal of the History of Economic Thought, 31, 143-60.

Angell, J. W. ([1926] 1965) The Theory of International Prices: History, Criticism, and Restatement, Augustus M. Kelley, New York, NY.

Arnon, A. (2010) Monetary Theory and Policy from Hume and Smith to Wicksell: Money, Credit, and the Economy, Cambridge University Press, New York, NY.

Bloomfield, A. I. (1975) Adam Smith and the Theory of International Trade. In A.S. Skinner and T. Wilson (eds) Essays on Adam Smith, Clarendon Press, Oxford, p.455-81.

Borio, C. (2014) The International Monetary and Financial System: Its Achilles Heel and What To Do About It, BIS Working Papers, No. 456, Bank for International Settlements, Basel, August.

Broz, J.L and Frieden, J.A. (2001) The Political Economy of International Monetary Relations, Annual Review of Political Science, 4, 317-43.

Bowley, M. ([1937] 1967) Nassau Senior and Classical Economics, Octagon Books, New York, NY.

Boyd, W. (1801) A Letter to the Right Honourable William Pitt, on the Influence of the Stoppage of Issues in Specie at the Bank of England, Wright, London. 
Blake, W. (1966) Observations on the Principles Which Regulate the Course of Exchange, in J. R. McCulloch (ed.) A Select Collection of Scarce and Valuable Tracts and Other Publications on Paper Currency and Banking, Augustus M. Kelley, New York, NY.

Blanchard, O. (2016) Currency Wars, Coordination, and Capital Controls, Prepared for the Asian Monetary Policy Forum, Singapore, May.

Bullard, J. and Singh, A. (2008) Worldwide Macroeconomic Stability and Monetary Policy Rules, Journal of Monetary Economics, 55 (Supplement), 34-47.

Bullard, J. (2014) Two Views of International Monetary Policy Coordination. Presented at 27th Asia/Pacific Business Outlook Conference, USC Marshall School of BusinessCIBER, Los Angeles, CA., April.

Cantillon, R. (1964) Essai sur la Nature du Commerce en General, Augustus M. Kelley, New York, NY.

Cheng, W. and Angus, S.D. (2012) The Cantillon Effect of Money Injection through Deficit Spending, Monash University Department of Economics Discussion Paper 12/12, Monash University, Melbourne, December.

Claessens, S., Stracca, L. and Warnock, F.E. (2015), International Dimensions of Conventional and Unconventional Monetary Policy, Journal of International Money and Finance, 76, 1-7.

Clarida, R., Gali, J. and Gertler, M. (2002) A Simple Framework for International Monetary Policy Analysis, Journal of Monetary Economics, 49, 879-904.

Cœuré, B. (2016) The Internationalisation of Monetary Policy, Journal of International Money and Finance, 67, 8-12.

DeVroey, M. (2016) A History of Macroeconomics: From Keynes to Lucas and Beyond, Cambridge University Press, New York, NY.

Dreger, C. and Wolters, J. (2014) Unconventional Monetary Policy and Money Demand, Deutsches Institut für Wirtschaftsforschung Discussion Paper no. 1382, Berlin.

Eagly, R. V. (1970) Adam Smith and the Specie-Flow Doctrine Scottish Journal of Political Economy 17, 61-68.

Eagly, R. V. (1974) The Structure of Classical Economic Theory, Oxford University Press, New York, NY.

Eichengreen, B. (2013) Currency War or International Policy Coordination, Journal of Policy Modelling, 35, 425-33.

Engel, C. (2015) International Coordination of Central Bank Policy, NBER Working Paper no. 20952, Cambridge, MA, February.

Feroli, M., Kashyap, A.K., Schoenholtz, K. and Shin, H.S. (2014) Market Tantrums and Monetary Policy, The Initiative on Global Markets, Chicago Booth Working Paper no. 101, Chicago, IL., September. 
Fetter, F. W. ([1965] 1978) Development of British Monetary Orthodoxy, 1797-1875, Augustus M. Kelley, New York, NY.

Frenkel, J.A. and Johnson, H.G. (eds) (1976) The Monetary Approach to the Balance of Payments, Allen and Unwin, London.

Frankel, J.A. (2015) International Coordination. 2015 Asia Economic Policy Conference Policy: Challenges in a Diverging Global Economy, Federal Reserve Bank of San Francisco, San Francisco, CA., November.

Frankel, J.A. (2016) International Coordination, NBER Working Paper Series, WP 21878, Cambridge, MA., January.

Frieden, J.A. and Broz, J.L. (2013) The Political Economy of International Monetary Policy Coordination, in G. Caprio (ed.) Handbook of Safeguarding Global Financial Stability: Political, Social, Cultural, and Economic Theories and Models, Elsevier, London, vol. 2, p.81-90.

Froyen, R.T. (2013) Macroeconomics: Theories and Policies, 10 ed., Pearson, New York, NY.

Garrison, R. (2008) Ahiakpor on Mises and "Forced Saving": A Rejoinder, History of Political Economy, 40, 397-405.

Gervaise, I. (1972) The System or Theory of the Trade of the World, in L. Silk (ed.) Mercantilist Views of Trade and Monopoly: Four Essays 1645-1720, Arno Press, New York, NY.

Girton, L. and Roper, D. (1978) J. Laurence Laughlin and the Quantity Theory of Money, Journal of Political Economy, 86, 599-625.

Harris, J. (1767) An Essay upon Money and Coins, G. Hawkins, London.

Hayek, F. A. ([1932] 1969) A Note on the Development of the Doctrine of Forced Saving, in Profits, Interest and Investment and Other Essays on the Theory of Industrial Fluctuations, Augustus M. Kelley, New York, NY.

Hoffmann, A. and Schnabl, G. (2016) Adverse Effects of Unconventional Monetary Policy, CATO Journal, 36, 449-84.

Horsefield, J. K. (1953) The Duties of a Banker (parts I and II), in T.S. Ashton and R. S. Sayers (eds) Papers in English Monetary History, Oxford University Press, London.

Hubbard, R.G., O’Brien, A.P. and Rafferty, M. (2012) Macroeconomics, Pearson, New York, NY.

Hume, D. (1970) Writings on Economics, The University of Wisconsin Press, Madison, WI.

Humphrey, T. M. and Keleher, R. E. (1982) The Monetary Approach to the Balance of Payments, Exchange Rates, and World Inflation, Praeger Publishers, New York, NY.

King, L. (1804) Thoughts on the Effects of the Bank Restrictions, Cadell and Davies, London. 
King, L. (1846) Selections from the Speeches and Writings of the Late Lord King, in E. Fortescue (ed.), Longman, Brown, Green, and Longmans, London.

Laidler, D. (1981) Adam Smith as Monetary Economist, Canadian Journal of Economics, 14, 185-200.

Leijonhufvud, A. (1994) Hicks, Keynes and Marshall, in Hagemann H. and Hamadou, O. (eds), The Legacy of Hicks: His Contributions to Economic Analysis, Routledge, London, p.147-62.

Lim, S.-Y. and Gan, P.-T. (2015) The Demand for Money and Economic Uncertainty, International Business Education Journal, 8, 15-21.

Lucas, R.E. and Nicolini, J.P. (2015) On the Stability of Money Demand, Federal Reserve Bank of Minneapolis Research Department Working Paper no. 718, Minneapolis, MN., September.

Mason, W. E. (1953) The Classical Theory of Adjustment to Unilateral Capital Transfers, Doctoral Dissertation Series no. 5155, University Microfilms, Ann Arbor, MI.

Mill, J. S. (1965) Collected Works of John Stuart Mill, vol.2, University of Toronto Press, Toronto.

Moreira, T.B., Tabak, B.M., Mendonca, M.J. and Sachsida, A, (2016) An Evaluation of the Non-Neutrality of Money, PLoS ONE, 11, e0145710.

Monroe, A. E. ([1923] 1965) Monetary Theory before Adam Smith, Peter Smith, Gloucester, MA.

O'Brien, D. P. (1978) The Classical Economists, Clarendon Press, New York, NY.

Obstfeld, M. and Rogoff, K. (2002) Global Implications of Self-Oriented National Monetary Rules, Quarterly Journal of Economics, 117, 503-35.

Paganelli, M. P. (2006) Hume and Endogenous Money, Eastern Economic Journal, 32, 533547.

Patinkin, D. (1965) Money, Interest, and Prices: An Integration of Monetary and Value Theory, Harper \& Row, New York, NY.

Petrella, F. (1968) Adam Smith's Rejection of Hume's Price-Specie-Flow Mechanism: A Minor Mystery Resolved, Southern Economic Journal, 34, p.365-74.

Rey, H. (2015) Dilemma not Trilemma: The Global Financial Cycle and Monetary Policy Independence, NBER Working Paper no. 21162, Cambridge, MA., May.

Ricardo, D. (1951) The Works and Correspondence of David Ricardo. 9 vols, Piero Straffa (ed.), Cambridge University Press, Cambridge, MA.

Romer, P. (2016) The Trouble with Macroeconomics, Commons Memorial Lecture of the Omicron Delta Epsilon Society, Fairhope, AL. 
Rotwein, E. ([1955] 1970) Introduction in David Hume, in E. Rotwein (ed.), David Hume: Writings on Economics, University of Wisconsin Press, Madison, WI., p.ix-cxi

Saccomanni, F. (2015) Monetary Spillovers? Boom and Bust? Currency Wars? The International Monetary System Strikes Back. BIS Special Governors' Meeting, Manila, February.

Salerno, J. T. (1980) The Doctrinal Antecedents of the Monetary Approach to the Balance of Payments, University Microfilms International, Ann Arbor, MI.

Salerno, J.T. (2012) A Reformulation of Austrian Business Cycle Theory in Light of the Financial Crisis, Quarterly Journal of Austrian Economics, 15, 3-44.

Sekine, T.T. (1973) The Discovery of International Monetary Equilibrium by Vanderlint, Cantillon, Gervaise and Hume, Economia Internazionale, 26, 262-82.

Smith, A. (1965) An Inquiry into the Nature and Causes of the Wealth of Nations, The Modern Library, New York, NY.

Taylor, J. B. (2013a) International Monetary Policy Coordination: Past, Present and Future. BIS Working Papers No 437, Bank of International Settlements, Basel, December.

Taylor, J.B. (2013b) International Monetary Coordination and the Great Deviation, Session on International Policy Coordination, American Economic Association Annual Meetings, San Diego, CA.

Taylor, J.B. (2016a) Rethinking the International Monetary System, CATO Journal, 36, 23950.

Taylor, J.B. (2016b) An International Monetary System Built on Sound Policy Rules, Keynote Address, International Conference on Macroeconomic Analysis and International Finance, University of Crete, Rethymno.

Taylor, A.M. and Taylor, M.P. (2004) The Purchasing Power Parity Debate, Journal of Economic Perspectives, 18, 135-58.

Thornton, H. ([1939] 1978) An Enquiry into the Nature and Effects of the Paper Credit of Great Britain, Augustus M. Kelley, New York, NY.

Vanderlint, J. (1914) Money Answers All Things, Johns Hopkins Press, Baltimore, MD.

Vickers, D. ([1959] 1968) Studies in the Theory of Money 1690-1776, Augustus M. Kelley, New York, NY.

Wheatley, J. (1819) A Report on the Reports of the Bank Committees, Longman, Hurst, Reese, Orme, and Brown, London.

Wu, C-Y. (1939) An Outline of International Price Theories, George Routledge \& Sons, London. 